UPPSALA UNIVERSITET
Working Paper 2007:23

Department of Economics

The legacy of the Swedish gift and inheritance tax, 1884-2004

Henry Ohlsson 
P.O. Box 513

SE-751 20 Uppsala

Sweden

Fax: +46184711478

THE LEGACY OF THE SWEDISH GIFT AND INHERITANCE TAX, 1884-2004

Henry Ohlsson

Papers in the Working Paper Series are published on internet in PDF formats.

Download from http://www.nek.uu.se or from S-WoPEC http://swopec.hhs.se/uunewp/ 


\title{
The legacy of the Swedish gift and inheritance tax, 1884-2004*
}

\author{
Henry Ohlsson
}

10 September 2007

\begin{abstract}
This paper has two objectives. The first is to study the revenue from the gift, inheritance, and estate taxes in Sweden during more than a century. The second is to focus on a unique episode during the second half of the 1940s when gifts and gift tax revenue exploded. This episode has never before been discussed in the research literature. It gives an extremely clear illustration of behavioral response to taxes in general, and the impact of expectations of future tax increases in particular. It is also a very interesting episode in the economic history of Sweden. I have access to aggregate tax revenue data since 1884 . Moreover, I have constructed a rich micro data set of all gifts reported during the period 1942-1949 in one county. A first main result is that gift tax revenue during the 1940s started to increase long before a new estate tax and increased wealth taxation were decided and implemented. The increase even began before the legislative process started. Second, both the number and the average values of gifts increased. Promissory notes were, in value, the most common way to give. Finally, gifts, inheritances, and estates were never important sources of tax revenue. Revenue as a share of GDP reached a peak already in the 1930s. The role of these taxes has instead primarily been equity and to provide integrity for other tax bases.
\end{abstract}

Keywords: gift tax, inheritance tax, estate tax, tax avoidance, expectations

EconLit subject descriptors: D100, D310, H240, N330, N340

Correspondence: Henry Ohlsson, Department of Economics, Uppsala University, Box 513, SE-751 20 Uppsala, Sweden, email <henry.ohlsson@nek.uu.se>.

*Helpful comments and suggestions from Lennart Berg, Per-Anders Edin, Rodney Edvinsson, Nils Elvander, C-H Hermansson, Sven-Olov Lodin, Johan Lönnroth, Leif Mutén, Katarina Nordblom, Jesper Roine, Agnar Sandmo, Håkan Selin, Daniel Waldenström, and from seminar participants at Uppsala (Economics, Economic History) and Lund (Economic History) are gratefully acknowledged. The usual disclaimer applies. My deceased father Knut Ohlsson was a historian and archive man. I am pretty sure that this would have been his favorite among my papers. 


\section{Introduction}

Taxes create burdens on economic agents as purchasing power is transferred from households and firms to the public sector. In addition, taxes may change the behavior of households and firms. Excess burdens might arise when agents move from high tax activities to low tax activities, from taxed activities to untaxed activities.

It is an important empirical task to provide evidence on how large these burdens and excess burdens of taxation are. Episodes with major changes in taxes that induce considerable changes in the behavior of economic agents provide one possible empirical approach.

The Swedish gift and inheritance tax was repealed in 2004. The inheritance tax was introduced 1884 while the tax on gifts was added in $1915 .^{1}$ There was also an estate tax during the period 1948-1958. These taxes were always controversial. One might say that they have generated more controversy than tax revenue. They became symbols for the ideological tension between the political left and the political right. Arguments about equity and equality of opportunity stood against property rights arguments. But these taxes also provided integrity for other tax bases, for example, the wealth tax. The existence of a gift tax made it, in other words, more difficult to avoid the wealth tax by giving wealth to others.

Looking at tax revenue it is evident that Sweden was struck by an epidemic of sudden generosity during the second half of the 1940s. Gift tax revenue in 1947 was twenty times higher than the annual averages before and after.

In the mid 1940s the Social Democrat finance minister Ernst Wigforss made his third attempt to introduce an estate tax in Sweden. ${ }^{2}$ The estate tax was an element in a comprehensive tax reform. The tax reform created a heated discussion in the political sphere. But the design of economic policy in general was very much on the political agenda during the years immediately after World War II. There was a strong polarization between the political left and the political right on issues such as economic planning. The discussion at the political level intersected with a discussion about legal principles. The focus on law was not parallelled by an interest for the economic actions of individuals at the micro level.

To my knowledge this is the first time that this gift episode is discussed in the research literature. It has been a completely neglected episode. ${ }^{3}$

The 1947 gift explosion is an extremely clear example of behavioral ef-

\footnotetext{
${ }^{1}$ There had, however, been taxes on estates from as early as 1698 .

${ }^{2}$ Wigforss was finance minister 1925-1926, 1932-1936, and 1936-1949. The first attempt to introduce an estate tax was made in 1928, the second 1933-1934.

${ }^{3}$ I have also checked the memoirs of leading politicians and news clip archives from the main newspapers at the time without finding anything about the gift episode.
} 
fects of taxes. It illustrates that behavior is affected not only by actual tax rates but also by expectations about future tax increases. The episode is also a fascinating part of Sweden's economic history. ${ }^{4}$

I have access to aggregate tax revenue data since 1884 . Moreover, I have a rich micro data set of all gifts reported during the period 1942-1949 in Dalarna, a county in the geographical middle of the country.

So what is the legacy of the Swedish gift and inheritance tax 1884-2004? My three main conclusions from the discussion in the paper are:

- A first main result is that gift tax revenue during the 1940s started to increase long before a new estate tax and increased wealth taxation was decided and implemented, starting even before the legislative process began.

- Second, both the number and the average values of gifts increased. Promissory notes were, in value, by far the most common way to give.

- Finally, gifts, inheritances, and estates were never important sources of tax revenue. Revenue as a share of GDP reached a peak already in the 1930s. The roles of these taxes have instead primarily been equity and to provide integrity for other tax bases.

The paper is structured as follows: I discuss the revenue from taxes on gifts, inheritances, and estates since 1884 in Section 2. Section 3 presents the episode in the mid 1940s when the revenue from the gift tax increased twentyfold. The evidence from the Dalarna micro data set is presented in Section 4. Section 5 reports the results from estimating econometric models using the Dalarna micro data. Section 6 concludes. There are three appendices. Appendix A presents the data sources and some descriptive statistics. The gift tax rates in the mid 1940s are reported in Appendix B. Appendix $\mathrm{C}$ is a chronology of the most important changes affecting inheritance, estate, and gift taxes in Sweden.

\section{Tax revenue since 1884}

When studying the long run evolution of tax revenue it is necessary to relate nominal tax revenue to some other macro aggregate. I have chosen to focus on nominal tax revenue as a share of nominal GDP at basic prices. This means that I not only deflate revenue with the increase in prices but also the increase on real production.

\footnotetext{
${ }^{4}$ The only comparable episode I can think of is the explosion of marriages in Sweden in December 1989. Changes in the pension system affecting pensions of future widows created strong economic incentives to marry before the end of 1989. The number of marriages in 1989 was almost three times the annual averages the years before and after.
} 


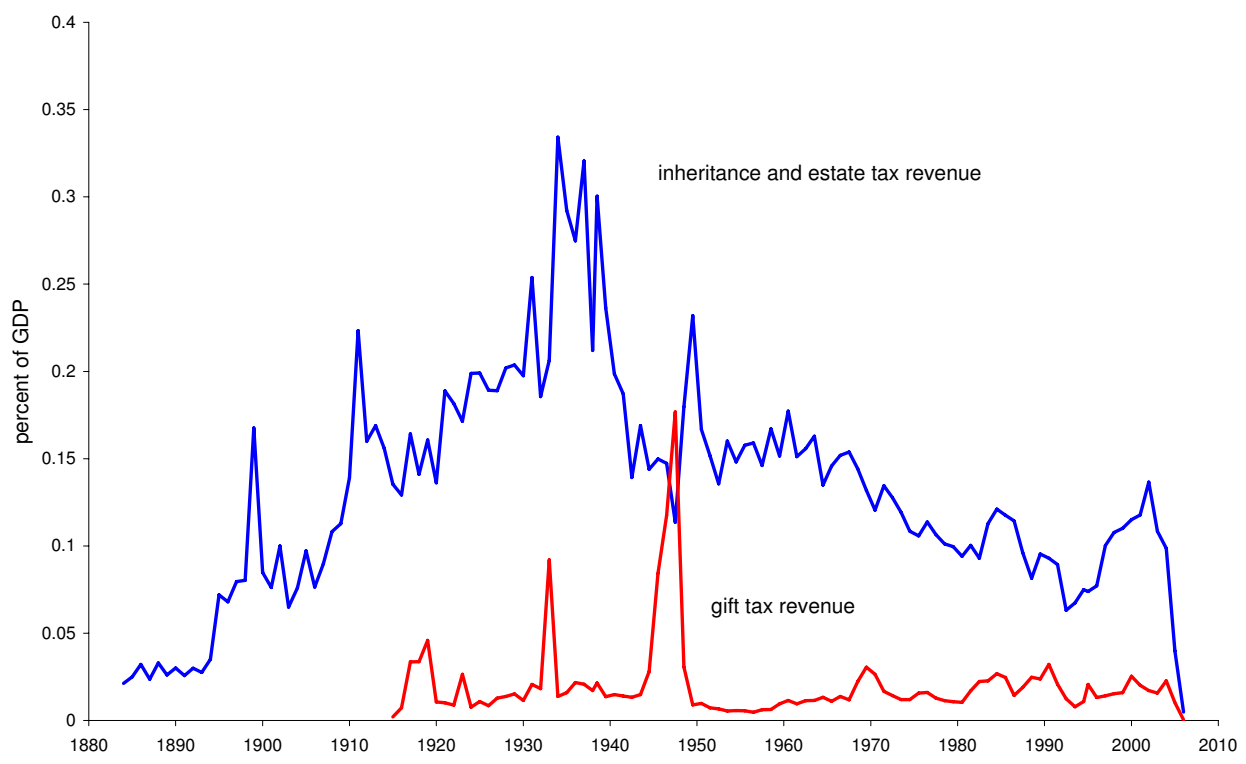

Figure 1: Revenue from taxes on inheritance, estates, and inter vivos gifts, 1884-2006, percent of GDP.

The main trends in tax revenue are very clear. Tax revenue from inheritance and estate taxes increased from 1884 when my data start until the end of the 1930s, see Figure 1. Annual tax revenue as a share of GDP was about 0.3 percent. Inheritance tax revenue as a share of total tax revenue was about 2.5 percent. There is a trend decrease thereafter. Gift tax revenue, on the other hand, has been stable on the long run since the introduction 1915 .

But in addition to the long run trends, tax revenue shows a lot of variation in the short run. There are distinct peaks in inheritance and estate tax revenue in 1899, 1911, 1934, and 1949/50. Gift tax revenue has three distinct peaks 1919, 1933, and 1947. But the 1947 peak is certainly the most important. In 1947, gift tax revenue was twenty times higher than the annual averages before and after. Gift tax revenue was higher than revenue from the inheritance tax. The revenue effect was, in other words, as if mortality had doubled in $1947 . .^{5}$

These developments can, of course, be related to the main changes in the taxes. ${ }^{6}$ The 1884 stamp ordinance made the estate report the basis for the inheritance tax. The rate was 0.5 percent of the estate if there were legal

\footnotetext{
${ }^{5}$ U.S. gift tax revenue peaked in 1935 and 1976, years before tax rate increases, see Joulfaian (2004). These peaks were, however, not as pronounced as the 1947 peak in Sweden.

${ }^{6}$ Appendix $\mathrm{C}$ is a chronology of when main changes affecting these taxes took place. Eberstein (1956) and Englund and Silfverberg (1997) are two sources for facts about the design of the taxes. These sources are, unfortunately, only available in Swedish.
} 
heirs, 0.6 percent otherwise. A more true inheritance tax was introduced in the 1894 stamp ordinance. There the maximum rate was 1.5 percent for children and spouses. The revenue peak in 1899 was the result of the 1899 stamp ordinance and a peak in mortality that year. ${ }^{7}$

The gift tax was introduced from 1915 by the 1914 inheritance and gift tax ordinance. The two taxes were integrated with each other. The maximum rate for children and spouses was increased to 4 percent.

In 1928, finance minister Wigforss put forward a private bill in Parliament to introduce an estate tax. This became an extremely hot topic in the 1928 parliamentary election campaign, which was very tense between the left and the right. The election was won by the conservatives.

The Social Democrats gained power in the next parliamentary election in 1932. The new minority government suggested the introduction of an estate tax in 1933. This was, however, rejected by Parliament. Instead the inheritance and gift taxes were increased in 1933. The maximum rate for children and spouses was increased to 20 percent, and a special wealth tax was introduced the following year. These tax changes are well correlated with the peak in gift tax revenue before the tax increases and the peak in inheritance tax revenue afterwards.

An estate tax was introduced from 1948 by the 1947 estate tax ordinance. In addition, an estate tax on gifts was combined with the estate tax to provide integrity to the tax base. The political process leading to this tax is discussed in the next section. In this case gift tax revenue also increased before the tax increase but to a much larger extent, and revenue from taxes on estates and inheritances increased afterwards.

Now there were four different taxes on transfers. The gift tax was integrated with the inheritance tax while the estate tax on gifts was integrated with the estate tax.

The estate tax was repealed from 1959. As the tax on inheritances was increased at the same time, however, revenue remained approximately the same. The maximum rate for children and spouses was increased to 60 percent, but the effective tax rates were lower than the nominal rates.

The tax rates were increased further in 1970. Now the maximum rate was increased to 65 percent. Two decades later rates were cut. From 1992 the maximum rate became 30 percent.

The gift and inheritance tax was repealed 17 December 2004. There is, however, still tax revenue from the taxes as there are lags before estate reports are filed and taxes are paid.

\footnotetext{
${ }^{7}$ The Spanish flu 1918/19 created the most distinct peak in mortality during the whole period 1884-2005. Excess mortality in 1918 corresponded to 0.6 percent of the population, but it mainly affected young people without wealth.
} 


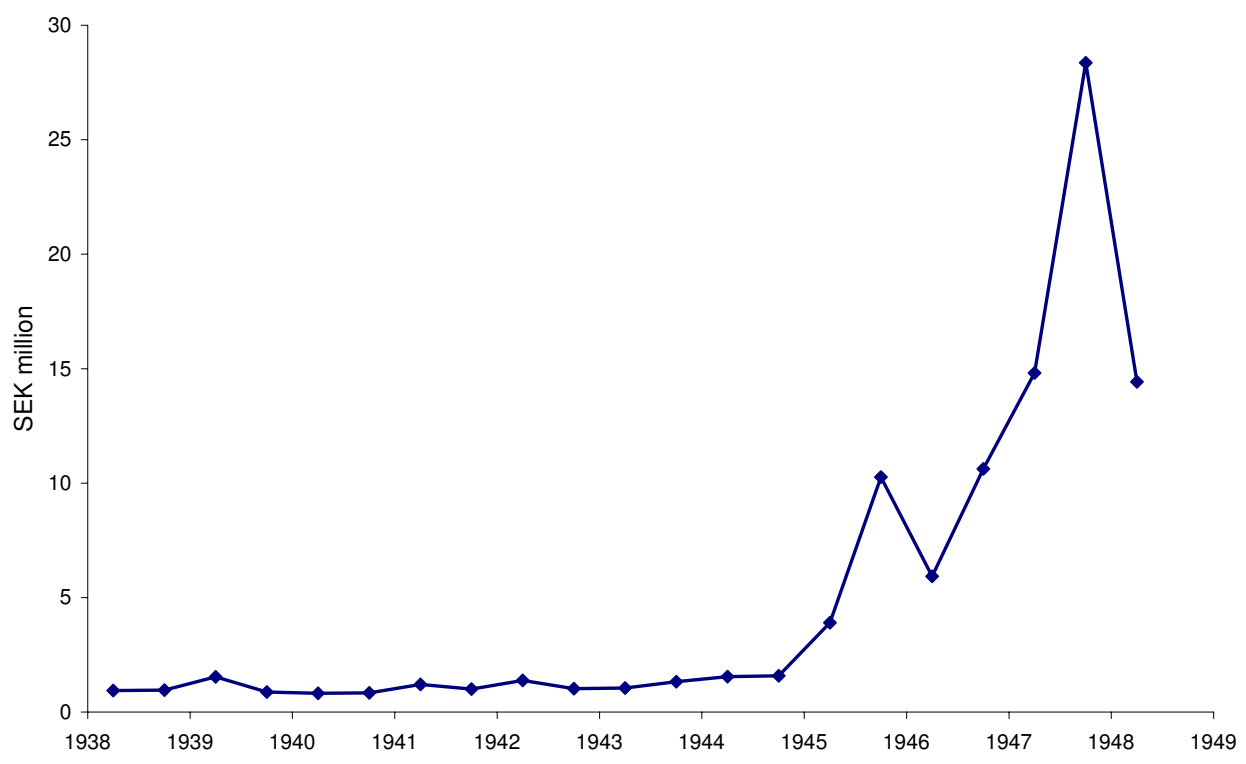

Figure 2: Gift tax revenue, biannual data, 1938:1-1948:1, SEK million.

\section{Gift taxes during the 1940s}

This section discusses the events leading to the gift explosion during the 1940s. It is possible to obtain semiannual data on gift tax revenue during the period 1938-1948. This is fortunate as this makes it possible to study the increase in gifts during the 1940s more closely.

Revenue was low and stable from 1938 until 1944, see Figure 2. During the first half of 1945 revenue began to increase. This increase accelerated during the second half of 1945. Then tax revenue decreased somewhat during the first half of 1946. But after this breathing space there was a rebound to the level of the year before during the second half of 1946. This increase continued during the first half of 1947 and accelerated (doubled) during the second half of that year. During the first half of 1948 revenue decreased by 50 percent.

The tax rates did not change during this period until 1948 nor did the design of the tax system. ${ }^{8}$ Revenue changes had to do with the number of gifts and the amounts given.

How can we understand and explain this development? There were, of course, uncertain and turbulent times at the end of World War II and immediately after. The transformation of societies from war to peace affected all areas. Tax policy was one of these. Elvander (1972), chapter II, is a detailed account of the political process of Swedish tax policy after the war. ${ }^{9}$ It is

\footnotetext{
${ }^{8}$ Appendix B presents the gift tax rates in the mid 1940s.

${ }^{9} \mathrm{I}$ give references even if these are only available in Swedish as it is important to report
} 
interesting to compare the development at the political level with that of the private economic sphere:

1944. The Social Democrats and the Trade Union Confederation presented a joint Post War Program in Spring 1944. The Communists supported the program. One of the objectives was to equalize income and wealth by, among other things, taxation. But there were no concrete tax reforms suggested.

In the private sphere gifts did not increase.

The first half of 1945. The Communists, who had gained increased support in the 1944 parliamentary election, suggested a one time tax on wealth in Parliament during the Spring sessions 1945. One argument was that this was a way of reducing public debt generated during the war. In 1940 all political parties had agreed in principle on a one time tax on wealth to be implemented later.

Now gifts started to increase.

The second half of 1945. Sweden had a grand coalition government during the war and until July 1945, when a Social Democrat government took office. The Trade Union Confederation made a statement in August about tax policy. The unions argued for increased taxes on bequests, wealth, and businesses and also for more progressive personal income taxes. An official central government tax committee was appointed in October.

In the private sphere gifts began to accelerate.

The counties were responsible for administrating the gift tax reports. The governor of Stockholm wrote to the Ministry of Finance in November 1945 to point out that there was a strong increase in gifts. He argued that not only the increase in the number of gifts and the amounts but also other circumstances suggested an intent to reduce the effects of a possible progressive one time wealth tax. The Ministry, therefore, asked all county governors to report the number of gifts and the amounts during 1944 and $1945 . .^{10}$

The Board of Post Offices was responsible for collecting the gift tax. In one of the very few other comments I have found about these events, the Board wrote in November 1946: ${ }^{11}$

The collection of gift tax shows a marked increase already from the month of December 1944. During the fiscal year 1944/45 2.5 million kronor more than during the previous fiscal year in gift tax thus flowed in. As the Board of Post Offices previously

\footnotetext{
the sources of my account of the events.

${ }^{10}$ This is reported in an enclosure to the final report of the central government tax committee, SOU (1946), p 444-445.

${ }^{11}$ Quoted in The Revenue Calculation of the National Accounting Board in the Budget Bill, Enclosure 1, p 36, The Minutes of Parliament 1947, my translation.
} 
has put forward in its letters to the National Accounting Board November 13, 1945 and April 17, 1946 concerning the calculation of stamp duty collection during the fiscal years 1945/46 and $1946 / 47$, the increase in gift tax collection probably has been brought about by fears of increased wealth taxation.

The first half of 1946. In June, the Social Democrats suggested the introduction of an estate tax instead of a one time wealth tax.

Gifts decreased during this period.

The second half of 1946. There were nationwide local elections in September. The Social Democrats had a tax policy program, including the estate tax. But this did not play a major role in the election campaign.

The official central government tax committee finished its report in November. The committee suggested an estate tax and a separate wealth tax instead of a one time wealth tax. It was also suggested that it would be possible to pay the estate tax in stocks.

In the private sphere gifts started to increase again.

The central government tax committee was well aware of the increase in gifts during 1945. The final report included an enclosure that reported the analysis done by the Ministry of Finance in 1945. The enclosure also included a more thorough analysis by the committee of gift reports in the City and the County of Stockholm during July-October 1945.

The first half of 194\%. This was the main period of political controversy. The deadline for submitting comments on the suggestions of the official central government was in February. There was a heated discussion in the daily papers and other places where politicians, economists, and law scholars were active. ${ }^{12}$ The Swedish Economic Association had a debate with a very critical introduction of Heckscher commented by Wigforss, see Nationalekonomiska Föreningen (1948). In April, Swedish Public Radio broadcasted a two hour long debate about the tax proposal. ${ }^{13}$

The tax discussion was, however, only one of many issues in a polarized political environment at this time. The more general discussion about economic planning was very much on the political agenda.

Private gifts continued to increase.

The second half of 194\%. Parliament decided in July according to the suggestions of the official government committee. The estate tax and increased

\footnotetext{
${ }^{12}$ Although published a year later, Eberstein (1948) uses many of the arguments against the estate tax put forth by law scholars.

${ }^{13} \mathrm{~A}$ recording of the debate is kept in The Swedish Public Radio Archive, Occ.09 Qaf, L-B 7.501, 106.696-8 and 106.697-6. No one makes any references to the gift explosion during the debate.
} 
wealth taxation were to be introduced from 1948. The estate tax was integrated with an estate tax on gifts to reduce tax avoidance. But this only applied to gifts made from 1948, so the estate tax on gifts was not immediate. There was a comment from a district judge pointing out the risk of tax avoidance before the estate tax was introduced and suggesting that gifts should be integrated from the day when the government submitted the estate tax bill to Parliament. Finance minister Wigforss, however, clearly responded that integration should take place from the time when the estate tax was introduced and not before that. ${ }^{14}$ He did not motivate this.

In the private sphere gifts doubled compared to the first half of the year.

There is to my knowledge no previous analysis of this gift episode in the research literature. Nor have I been able to find any discussion about the episode in the memoirs of leading politicians at the time, such as the finance minister Wigforss (1954), the prime minister Erlander (1973), and the opposition leader Ohlin (1975). ${ }^{15}$ I have also checked the Uppsala press archives, covering 50 daily papers since 1945, for anything about the episode without any success. ${ }^{16}$

The only reference to the 1947 gift episode I have found is in the report of the 1957 official government committee on inheritance taxation. The committee writes: ${ }^{17}$

Finally it should be mentioned that the exceptionally big return of the gift tax during the fiscal years 1945/46-1947/48 should be seen against the background of the increase in primarily estate taxation first expected then decided, but not coming into force until January 1, 1948.

An important issue is whether the households were right in advancing their transfers to younger generations. Was it rational to take the actions that the households did? In the short run it was quite obvious that this was the case as the estate tax on gifts did not apply for gifts made before 1948. But with a more long run perspective this becomes more of an open question. It depends on how much earlier the transfer was made compared to when it had been made as a bequest or later gift. This is an important topic for future research as it will shed more light on the question of the effects of taxes on behavior.

\footnotetext{
${ }^{14}$ The Royal Bill 212, p 377-378.

${ }^{15}$ In the prime minister Tage Erlander's diary for 31 March 1947 he is worried about a gift of stock to his wife from his father in law, see Erlander (2001), p 168. He writes that he will see to it that gift tax is paid at the highest possible rate, and expects that the opportunity for the political opposition to make an issue of this gift would be very small.

${ }^{16}$ In addition, I have also unsuccessfully checked the journal of the Swedish Taxpayers Association for texts about the gift episode.

${ }^{17} \mathrm{SOU}$ (1957), p 17, my translation.
} 
In addition, it is obvious that there was a clear correlation between gifts and politics. But what was the causality between the events in the political and the private sphere? On the one hand, was the giving a reaction on policy based on private economic considerations? Or were there political motives for the giving? I regard it as less likely that the giving had direct political motives, this was in any case not reflected in the political discussion. Instead it is more likely that private concerns were more important.

On the other hand, did the opinions among those giving form the political basis for the opposition to the estate tax? This seems more likely to me. But the question of causality in this case is an important topic for future research about Sweden's economic history.

\section{IOU: Micro data evidence from the county of Dalarna}

The micro data studied in this section come from the county of Dalarna, in the geographical middle of Sweden. ${ }^{18}$ There were slightly more than 250,000 inhabitants in the county during the second half of the 1940s. As far as I have been able to find, there are no as rich data available for any other county. ${ }^{19}$ Figure 3 shows the development of gift tax revenue and the underlying gift amounts during the period 1942-1949.

If we compare with tax revenue at the national level, see Figure 2, it is clear that the evolution of tax revenue in Dalarna is highly correlated with the total in the country. ${ }^{20}$ The figure also shows that tax revenue follows the total gift amount very closely. Tax revenue as a share of the total gift amount is mostly very close to 5 percent.

The total gift amount in Dalarna during 1947 was almost SEK 12 million, see Table 1 . This was about twenty times more than the annual average during the period 1942-1945. The increase in the total amount came bout both because the number of gifts and their average amount increased. The 2005 value of the total gift amount corresponds to SEK 200 million, EUR 22 million, USD 27 million, and GBP 15 million.

The table also reports different measures of the spread in gift amounts. There is no evidence that the spread increased during the gift explosion 1947.

Statistics Sweden provided an estimate of total wealth in each county in 1947. This is one of the few years that such an estimate is available. Esti-

\footnotetext{
${ }^{18}$ The county had a different name at the time but the province has always been known as Dalarna. This is also nowadays the official name of the county.

${ }^{19}$ Appendix A provides more information about the data set.

${ }^{20}$ The small peak in 1943 was partly the result of a large gift of stocks from an industrialist to his children.
} 


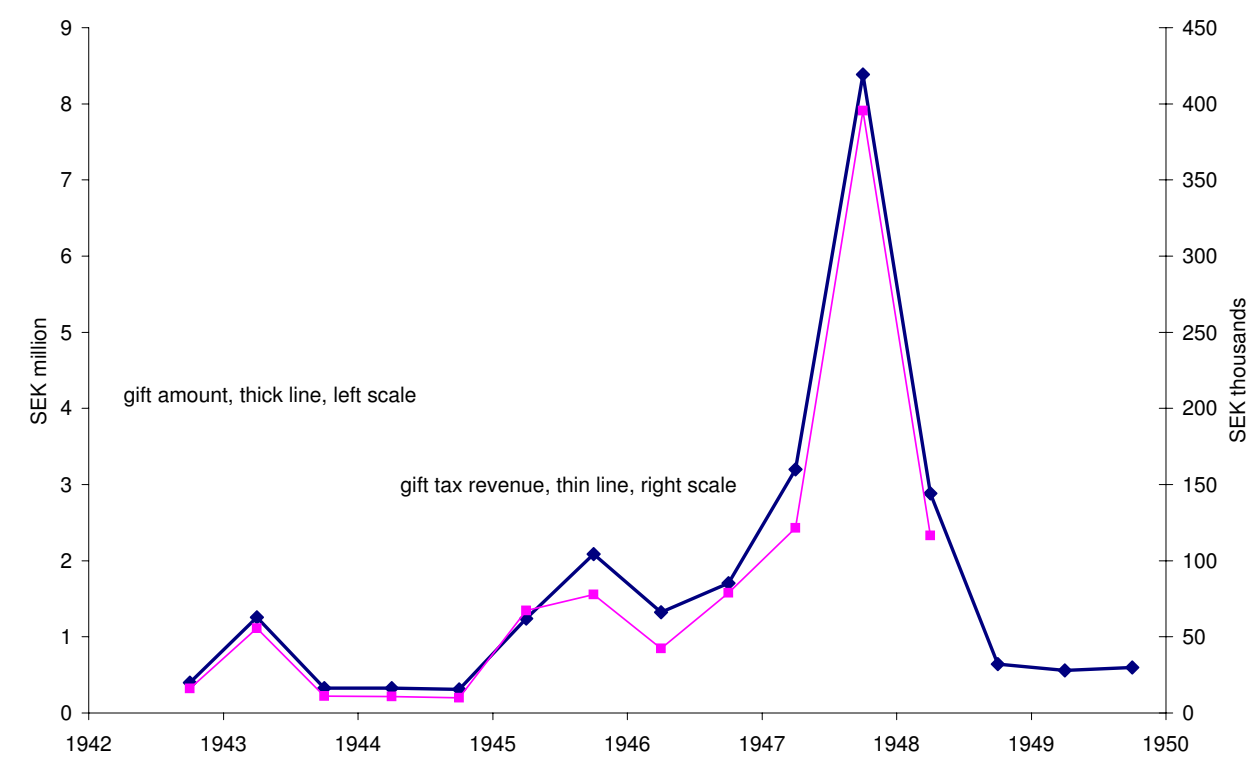

Figure 3: Gift amount and gift tax revenue in Dalarna, biannual data, 1942:2-1949:2.

mated wealth in Dalarna in 1947 was SEK 864.1 million. ${ }^{21}$ It is, therefore, possible to relate the total gift amount in 1947 to total wealth the same year. Total gifts as a share of county wealth is 1.40 percent. Some might regard this share as small. But the share is in the neighborhood of the annual transfer of wealth by bequests.

The data set has information on which type of asset that was transferred as a gift. Figure 4 shows the total values given of the five main asset types used during the period 1942-1949. The main type of asset used, in value, during the gift explosion 1945-1947 were promissory notes. Cash and stocks also increased but much less. The amounts of real estate and farm property were never considerable. There was a long tradition in Sweden to use promissory notes. Lindgren (2002) shows how promissory notes played an important role in providing credit in the 19th century.

The analysis done by the central government tax committee, reported in SOU (1946), showed that promissory notes also was the most important asset given in Stockholm during July-October 1945. About 43 percent of the gift amount was in promissory notes, 40 percent was in stocks and bonds, while 10 percent was in cash.

\footnotetext{
${ }^{21}$ Skattetaxeringarna, 1948, Förmögenhetsfördelningen 1947, p 60*.
} 
Table 1: Gifts in Dalarna.

\begin{tabular}{lcccccccc} 
& 1942 & 1943 & 1944 & 1945 & 1946 & 1947 & 1948 & 1949 \\
\hline number of gifts & 48 & 96 & 70 & 185 & 204 & 564 & 234 & 122 \\
total gifts, SEK thousands & 520 & 1,611 & 644 & 3,343 & 3,035 & 11,752 & 3,533 & 1,172 \\
average gift, SEK thousands & 10.8 & 16.8 & 9.2 & 18.1 & 14.9 & 20.8 & 15.1 & 9.6 \\
median gift, SEK thousands & 5.9 & 10.0 & 6.3 & 10.0 & 10.0 & 12.5 & 9.9 & 7.0 \\
P10 gift, SEK thousands & 3.1 & 3.8 & 3.3 & 3.5 & 4.2 & 4.0 & 4.0 & 3.1 \\
P90 gift, SEK thousands & 14.0 & 32.4 & 17.2 & 33.3 & 33.9 & 50.0 & 30.0 & 15.0 \\
Gini coefficient & 0.5308 & 0.5116 & 0.4156 & 0.5211 & 0.4464 & 0.4957 & 0.4712 & 0.4118 \\
coefficient of variation & 1.657 & 1.200 & 1.125 & 1.322 & 1.040 & 1.059 & 1.031 & 1.180 \\
standard deviation of logs & 0.791 & 0.903 & 0.694 & 0.997 & 0.789 & 0.951 & 0.856 & 0.774 \\
\hline
\end{tabular}

Note. P10 and P90 refer to percentiles in the gift distribution. 


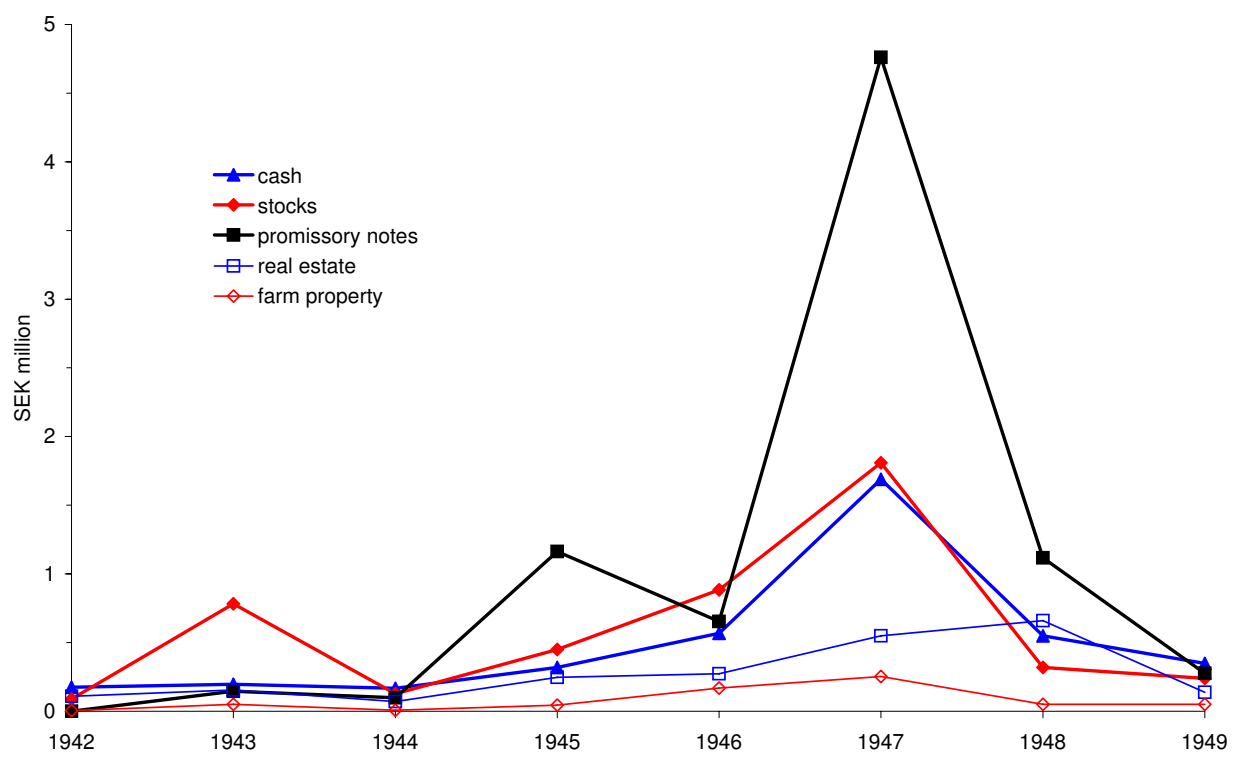

Figure 4: Gift amounts in Dalarna, annual data, 1942-1949.

About 80 percent of the total annual gift amounts in Dalarna were from parents. An additional 10 percent were from relatives on the father's and the mother's sides. Women received as much as men during most years, but men received more than women in 1943 and 1947. About 35 percent of the amount given in 1947 went to minors. This was a higher share than the other years.

\section{$5 \quad$ Econometric evidence}

I have collected the evidence from econometric analyses in this section. First, I study total amounts. Table 2 reports the results from estimations of gift amount models. It should be stressed that these models are conditional on that there is a gift. I cannot estimate models for the likelihood of gifts using the present data set.

There are no significant differences in the gift amounts received by women and men, see column 1 in Table 2 . Minors receive 50 percent more than other recipients. I have included dummy variables for the five most common occupations. Gifts to farm workers and farmers are significantly lower while gifts to engineers are significantly higher than gifts to others.

I have also included dummy variables for the five most common towns and villages among those receiving gifts. Falun and Borlänge were the two major towns in the county. Gifts were higher for those living in these two towns compared to those living elsewhere. In particular, gifts in Borlänge were 50 percent higher than elsewhere. 
Table 2: Gift amounts received, logarithm, OLS.

\begin{tabular}{|c|c|c|c|c|c|c|}
\hline sample period: & 1942-1949 & 1947 only & $1942-1949$ & $1942-1949$ & 1942-1949 & $1942-1949$ \\
\hline \multicolumn{7}{|l|}{ recipient: } \\
\hline woman & $\begin{array}{r}-0.031 \\
(0.59)\end{array}$ & $\begin{array}{r}-0.057 \\
(0.67)\end{array}$ & $\begin{array}{l}0.033 \\
(0.72)\end{array}$ & $\begin{array}{l}0.042 \\
(0.90)\end{array}$ & $\begin{array}{l}0.030 \\
(0.66)\end{array}$ & \\
\hline \multirow[t]{2}{*}{ minor } & 0.507 & 0.584 & & & & \\
\hline & $(8.01)$ & $(5.55)$ & & & & \\
\hline farm worker & $\begin{array}{c}-0.481 \\
(3.60)\end{array}$ & -0.496 & & & & \\
\hline farmer & $\begin{array}{r}-0.272 \\
(2.72)\end{array}$ & $\begin{array}{c}-0.430 \\
(2.29)\end{array}$ & & & & \\
\hline merchant & $\begin{array}{l}0.030 \\
(0.16)\end{array}$ & $\begin{array}{l}0.053 \\
(0.23)\end{array}$ & & & & \\
\hline student & $\begin{array}{c}0.236 \\
(1.80)\end{array}$ & $\begin{array}{l}0.144 \\
(0.74)\end{array}$ & & & & \\
\hline engineer & $\begin{array}{l}0.528 \\
(3.21)\end{array}$ & $\begin{array}{l}0.291 \\
(1.29)\end{array}$ & & & & \\
\hline Falun & $\begin{array}{l}0.199 \\
(2.93)\end{array}$ & $\begin{array}{c}0.223 \\
(2.00)\end{array}$ & $\begin{array}{r}0.341 \\
(5.41)\end{array}$ & & & \\
\hline Borlänge & $\begin{array}{l}0.484 \\
(4.64)\end{array}$ & $\begin{array}{r}0.562 \\
(3.03)\end{array}$ & $\begin{array}{r}0.550 \\
(5.34)\end{array}$ & & & \\
\hline Orsa & $\begin{array}{l}0.086 \\
(0.70)\end{array}$ & $\begin{array}{r}-0.308 \\
(1.04)\end{array}$ & $\begin{array}{l}-0.155 \\
(1.50)\end{array}$ & & & \\
\hline Mora & $\begin{array}{l}-0.006 \\
(0.06)\end{array}$ & $\begin{array}{l}0.073 \\
(0.54)\end{array}$ & $\begin{array}{l}0.049 \\
(0.47)\end{array}$ & & & \\
\hline Ludvika & $\begin{array}{l}-0.057 \\
(0.50)\end{array}$ & $\begin{array}{l}-0.232 \\
(1.44)\end{array}$ & $\begin{array}{l}0.128 \\
(1.17)\end{array}$ & & & \\
\hline \multicolumn{7}{|l|}{ donor: } \\
\hline parents & reference & reference & reference & reference & & \\
\hline father's side & $\begin{array}{r}-0.557 \\
(6.31)\end{array}$ & $\begin{array}{c}-0.705 \\
(4.77)\end{array}$ & $\begin{array}{r}-0.263 \\
(3.18)\end{array}$ & $\begin{array}{c}-0.246 \\
(2.99)\end{array}$ & & \\
\hline mother's side & $\begin{array}{r}-0.364 \\
(4.32)\end{array}$ & $\begin{array}{r}-0.640 \\
(5.10)\end{array}$ & $\begin{array}{l}-0.214 \\
(2.74)\end{array}$ & $\begin{array}{r}-0.195 \\
(2.47)\end{array}$ & & \\
\hline spouse & $\begin{array}{c}-0.012 \\
(0.04)\end{array}$ & $\begin{array}{c}-0.522 \\
(1.08)\end{array}$ & $\begin{array}{c}-0.028 \\
(0.10)\end{array}$ & $\begin{array}{l}-0.041 \\
(0.15)\end{array}$ & & \\
\hline siblings & $\begin{array}{c}-0.446 \\
(2.29)\end{array}$ & $\begin{array}{c}-0.705 \\
(1.87)\end{array}$ & $\begin{array}{r}-0.679 \\
(3.86)\end{array}$ & $\begin{array}{c}-0.686 \\
(3.85)\end{array}$ & & \\
\hline children & $\begin{array}{r}-0.911 \\
(2.93)\end{array}$ & $\begin{array}{r}-1.695 \\
(4.05)\end{array}$ & $\begin{array}{r}-0.897 \\
(3.10)\end{array}$ & $\begin{array}{r}-0.970 \\
(3.31)\end{array}$ & & \\
\hline not related & $\begin{array}{c}-0.369 \\
(1.82)\end{array}$ & $\begin{array}{l}-1.081 \\
(2.25)\end{array}$ & $\begin{array}{l}-0.482 \\
(2.46)\end{array}$ & $\begin{array}{l}-0.500 \\
(2.51)\end{array}$ & & \\
\hline \multicolumn{7}{|l|}{ year: } \\
\hline 1942 & $\begin{array}{l}0.257 \\
(0.84)\end{array}$ & & $\begin{array}{c}-0.063 \\
(0.37)\end{array}$ & $\begin{array}{c}-0.099 \\
(0.57)\end{array}$ & $\begin{array}{c}-0.030 \\
(0.66)\end{array}$ & $\begin{array}{c}-0.031 \\
(0.19)\end{array}$ \\
\hline 1943 & $\begin{array}{l}0.117 \\
(0.67)\end{array}$ & & $\begin{array}{c}0.388 \\
(2.71)\end{array}$ & $\begin{array}{c}0.473 \\
(3.28)\end{array}$ & $\begin{array}{c}0.459 \\
(3.20)\end{array}$ & $\begin{array}{r}0.451 \\
(3.22)\end{array}$ \\
\hline 1944 & reference & & reference & reference & reference & reference \\
\hline 1945 & $\begin{array}{l}0.359 \\
(2.51)\end{array}$ & & $\begin{array}{c}0.355 \\
(2.77)\end{array}$ & $\begin{array}{c}0.420 \\
(3.28)\end{array}$ & $\begin{array}{c}0.463 \\
(3.63)\end{array}$ & $\begin{array}{r}0.471 \\
(3.77)\end{array}$ \\
\hline 1946 & $\begin{array}{l}0.295 \\
(2.09)\end{array}$ & & $\begin{array}{r}0.335 \\
(2.66)\end{array}$ & $\begin{array}{r}0.380 \\
(3.00)\end{array}$ & $\begin{array}{c}0.424 \\
(3.35)\end{array}$ & $\begin{array}{c}0.435 \\
(3.53)\end{array}$ \\
\hline 1947 & $\begin{array}{l}0.565 \\
(4.23)\end{array}$ & & $\begin{array}{c}0.595 \\
(5.13)\end{array}$ & $\begin{array}{r}0.627 \\
(5.40)\end{array}$ & $\begin{array}{c}0.664 \\
(5.73)\end{array}$ & $\begin{array}{c}0.668 \\
(5.93)\end{array}$ \\
\hline 1948 & $\begin{array}{l}0.242 \\
(1.69)\end{array}$ & & $\begin{array}{c}0.390 \\
(3.15)\end{array}$ & $\begin{array}{r}0.381 \\
(3.06)\end{array}$ & $\begin{array}{r}0.418 \\
(3.36)\end{array}$ & $\begin{array}{c}0.424 \\
(3.49)\end{array}$ \\
\hline 1949 & $\begin{array}{l}0.037 \\
(0.25) \\
\end{array}$ & & $\begin{array}{l}0.060 \\
(0.44) \\
\end{array}$ & $\begin{array}{l}0.064 \\
(0.47) \\
\end{array}$ & $\begin{array}{l}0.031 \\
(0.23) \\
\end{array}$ & $\begin{array}{l}0.026 \\
(0.19) \\
\end{array}$ \\
\hline$R^{2}$ & 0.209 & 0.232 & 0.119 & 0.083 & 0.057 & 0.059 \\
\hline adjusted $R^{2}$ & 0.192 & 0.201 & 0.107 & 0.075 & 0.052 & 0.054 \\
\hline$F$, model, sign. & 0.000 & 0.000 & 0.000 & 0.000 & 0.000 & 0.000 \\
\hline root MSE & 0.815 & 0.824 & 0.862 & 0.875 & 0.891 & 0.889 \\
\hline $\mathrm{n}$ of observations & 1,173 & 465 & 1,460 & 1,471 & 1,498 & 1,518 \\
\hline
\end{tabular}


I have less information about the donor but I know the family relationship between the donor and the recipient. Gifts from relatives on the father's side and the mother's side are significantly smaller than gifts from parents. The same is true for gifts from siblings and gifts from children. Gifts from 1945, 1946, and 1947 are significantly higher than the gifts in other years. This further strengthens the conclusion that the gift amounts increased during the gift episode and not only the number of gifts.

The second column in Table 2 reports an estimation for 1947 gifts only. The idea is to check whether the estimated coefficients remain the same when the sample is limited to a single year. This also seems to be the case as there are no major differences between column 1 and column 2 .

There are, however, many missing observations for the variable "title", see Appendix A, which is used to classify minors and the five occupations. These variables are dropped in column 3 of Table 2 . The number of observations increases from slightly less than 1,200 to slightly less than 1,500. This does not, however, change the estimated coefficients considerably.

I, step by step, drop other variables to increase the number of observations and to compare the estimated coefficients in columns 4-6. The gift amount in 1947 was almost 70 percent higher than in the reference year according to the most parsimonious specification in column 6 .

Second, I estimate probability models for choosing particular assets. The five main assets used in the sample are:

- cash

- stocks

- promissory notes

- real estate

- farm property

In some cases a gift combines several different assets. I have used a wide definition of the dependent variable in the probability models. It equals one if the particular asset is included among the assets given, and zero otherwise. Table 3 reports the estimation results.

Minors are more likely than others to receive stocks and promissory notes, but less likely than others to receive cash, real estate, and farm property. If we look at different occupations, farm workers are more likely than others to receive cash and farm property, whereas farmers are less likely than others to receive stocks and more likely to receive real estate and farm property. The probabilities of stocks and real estate are higher for students but the probability of cash is lower. Engineers are less likely than other to receive cash and more likely than others to get promissory notes.

Recipients from Falun are more likely to get stocks and promissory notes and less likely to get real estate. The probabilities of stocks and promissory notes are lower and the probability of farm property is higher than for others for recipients from Orsa. Those from Mora are more likely to get stocks, 
Table 3: Probability of giving particular assets, probit models, marginal effects.

\begin{tabular}{|c|c|c|c|c|c|}
\hline & cash & stocks & $\begin{array}{c}\text { promissory } \\
\text { notes }\end{array}$ & $\begin{array}{c}\text { real } \\
\text { estate }\end{array}$ & $\begin{array}{c}\text { farm } \\
\text { property }\end{array}$ \\
\hline \multicolumn{6}{|l|}{ recipient: } \\
\hline woman & $\begin{array}{l}0.055 \\
(1.80)\end{array}$ & $\begin{array}{c}0.012 \\
(0.47)\end{array}$ & $\begin{array}{c}0.028 \\
(1.08)\end{array}$ & $\begin{array}{c}0.011 \\
(0.50)\end{array}$ & $\begin{array}{c}-0.004 \\
(0.38)\end{array}$ \\
\hline minor & $\begin{array}{c}-0.249 \\
(7.16)\end{array}$ & $\begin{array}{c}0.125 \\
(3.93)\end{array}$ & $\begin{array}{c}0.304 \\
(8.82)\end{array}$ & $\begin{array}{r}-0.087 \\
(3.38)\end{array}$ & $\begin{array}{c}-0.042 \\
(3.00)\end{array}$ \\
\hline farm worker & $\begin{array}{c}0.199 \\
(2.47)\end{array}$ & & $\begin{array}{c}-0.121 \\
(1.50)\end{array}$ & $\begin{array}{c}0.049 \\
(0.91)\end{array}$ & $\begin{array}{c}0.100 \\
(3.21)\end{array}$ \\
\hline farmer & $\begin{array}{r}-0.081 \\
(1.49)\end{array}$ & $\begin{array}{c}-0.158 \\
(3.05)\end{array}$ & & $\begin{array}{r}0.100 \\
(2.38)\end{array}$ & $\begin{array}{r}0.158 \\
(5.75)\end{array}$ \\
\hline merchant & $\begin{array}{c}0.016 \\
(0.15)\end{array}$ & $\begin{array}{l}0.152 \\
(1.59)\end{array}$ & $\begin{array}{l}0.124 \\
(1.25)\end{array}$ & $\begin{array}{c}-0.102 \\
(1.56)\end{array}$ & \\
\hline student & $\begin{array}{r}-0.148 \\
(2.15)\end{array}$ & $\begin{array}{c}0.149 \\
(2.20)\end{array}$ & $\begin{array}{c}0.095 \\
(1.35)\end{array}$ & $\begin{array}{c}0.144 \\
(2.26)\end{array}$ & \\
\hline engineer & $\begin{array}{r}-0.208 \\
(2.47)\end{array}$ & $\begin{array}{c}-0.065 \\
(0.82)\end{array}$ & $\begin{array}{c}0.354 \\
(3.88)\end{array}$ & $\begin{array}{c}-0.010 \\
(0.16)\end{array}$ & \\
\hline Falun & $\begin{array}{c}-0.009 \\
(0.23)\end{array}$ & $\begin{array}{c}0.083 \\
(2.46)\end{array}$ & $\begin{array}{r}0.097 \\
(2.75)\end{array}$ & $\begin{array}{r}-0.087 \\
(3.11)\end{array}$ & \\
\hline Borlänge & $\begin{array}{l}-0.049 \\
(0.81)\end{array}$ & $\begin{array}{c}0.015 \\
(0.28)\end{array}$ & $\begin{array}{c}0.078 \\
(1.35)\end{array}$ & $\begin{array}{c}0.001 \\
(0.02)\end{array}$ & $\begin{array}{c}-0.018 \\
(1.03)\end{array}$ \\
\hline Orsa & $\begin{array}{c}-0.049 \\
(0.73)\end{array}$ & $\begin{array}{c}-0.160 \\
(2.55)\end{array}$ & $\begin{array}{c}-0.178 \\
(2.15)\end{array}$ & $\begin{array}{c}0.064 \\
(1.29)\end{array}$ & $\begin{array}{c}0.089 \\
(3.37)\end{array}$ \\
\hline Mora & $\begin{array}{c}-0.199 \\
(3.53)\end{array}$ & $\begin{array}{r}0.172 \\
(3.14)\end{array}$ & $\begin{array}{r}0.127 \\
(2.29)\end{array}$ & $\begin{array}{c}0.203 \\
(4.03)\end{array}$ & $\begin{array}{l}0.016 \\
(0.78)\end{array}$ \\
\hline Ludvika & $\begin{array}{c}-0.074 \\
(1.06)\end{array}$ & $\begin{array}{c}-0.032 \\
(0.59)\end{array}$ & $\begin{array}{r}0.238 \\
(3.68)\end{array}$ & $\begin{array}{c}-0.057 \\
(1.11)\end{array}$ & $\begin{array}{l}-0.001 \\
(0.05)\end{array}$ \\
\hline parents & reference & reference & reference & reference & reference \\
\hline father's side & $\begin{array}{l}0.064 \\
(1.18)\end{array}$ & $\begin{array}{l}-0.024 \\
(0.59)\end{array}$ & $\begin{array}{l}-0.068 \\
(1.70)\end{array}$ & $\begin{array}{l}-0.040 \\
(1.10)\end{array}$ & $\begin{array}{l}-0.003 \\
(0.21)\end{array}$ \\
\hline mother's side & $\begin{array}{l}0.019 \\
(0.36)\end{array}$ & $\begin{array}{r}-0.082 \\
(2.05)\end{array}$ & $\begin{array}{l}0.034 \\
(0.79)\end{array}$ & $\begin{array}{l}-0.062 \\
(1.77)\end{array}$ & $\begin{array}{l}0.006 \\
(0.35)\end{array}$ \\
\hline spouse & $\begin{array}{c}-0.196 \\
(1.31)\end{array}$ & $\begin{array}{l}0.180 \\
(1.15)\end{array}$ & & $\begin{array}{c}-0.039 \\
(0.37)\end{array}$ & \\
\hline siblings & $\begin{array}{c}-0.084 \\
(0.81)\end{array}$ & & & $\begin{array}{c}0.400 \\
(3.87)\end{array}$ & \\
\hline children & $\begin{array}{l}0.329 \\
(1.62)\end{array}$ & & & $\begin{array}{c}-0.034 \\
(0.30)\end{array}$ & $\begin{array}{l}0.031 \\
(0.53)\end{array}$ \\
\hline not related & $\begin{array}{l}0.164 \\
(1.35)\end{array}$ & $\begin{array}{l}0.006 \\
(0.05)\end{array}$ & & $\begin{array}{l}-0.050 \\
(0.72)\end{array}$ & \\
\hline \multicolumn{6}{|l|}{ year: } \\
\hline 1942 & $\begin{array}{l}0.387 \\
(1.68)\end{array}$ & $\begin{array}{c}-0.031 \\
(0.19)\end{array}$ & & & \\
\hline 1943 & $\begin{array}{r}-0.172 \\
(2.05)\end{array}$ & $\begin{array}{c}0.198 \\
(1.81)\end{array}$ & & $\begin{array}{c}0.101 \\
(1.36)\end{array}$ & \\
\hline 1944 & reference & reference & reference & reference & reference \\
\hline 1945 & $\begin{array}{c}-0.240 \\
(3.65)\end{array}$ & $\begin{array}{c}0.108 \\
(1.29)\end{array}$ & $\begin{array}{c}0.392 \\
(3.93)\end{array}$ & $\begin{array}{l}0.026 \\
(0.49)\end{array}$ & $\begin{array}{c}0.047 \\
(1.47)\end{array}$ \\
\hline 1946 & $\begin{array}{l}-0.147 \\
(2.05)\end{array}$ & $\begin{array}{l}0.138 \\
(1.62)\end{array}$ & $\begin{array}{l}0.105 \\
(1.15)\end{array}$ & $\begin{array}{r}-0.020 \\
(0.40)\end{array}$ & $\begin{array}{r}0.143 \\
(3.26)\end{array}$ \\
\hline 1947 & $\begin{array}{r}-0.191 \\
(2.66)\end{array}$ & $\begin{array}{l}0.041 \\
(0.55)\end{array}$ & $\begin{array}{c}0.400 \\
(4.88)\end{array}$ & $\begin{array}{l}-0.048 \\
(1.02)\end{array}$ & $\begin{array}{c}0.052 \\
(2.14)\end{array}$ \\
\hline 1948 & $\begin{array}{c}-0.111 \\
(1.49)\end{array}$ & $\begin{array}{r}-0.038 \\
(0.49)\end{array}$ & $\begin{array}{c}0.418 \\
(4.11)\end{array}$ & $\begin{array}{l}0.108 \\
(1.80)\end{array}$ & $\begin{array}{l}0.010 \\
(0.37)\end{array}$ \\
\hline 1949 & $\begin{array}{c}-0.134 \\
(1.79) \\
\end{array}$ & $\begin{array}{r}-0.077 \\
(1.02) \\
\end{array}$ & $\begin{array}{c}0.346 \\
(3.25) \\
\end{array}$ & $\begin{array}{l}0.047 \\
(0.81) \\
\end{array}$ & $\begin{array}{r}0.102 \\
(2.38) \\
\end{array}$ \\
\hline dep. variable, mean & 0.329 & 0.229 & 0.258 & 0.160 & 0.056 \\
\hline log likelihood & -677.6 & -580.5 & -545.3 & -450.5 & -199.0 \\
\hline pseudo $R^{2}$ & 0.096 & 0.088 & 0.192 & 0.133 & 0.218 \\
\hline$\chi^{2}$, sign. & 0.000 & 0.000 & 0.000 & 0.000 & 0.000 \\
\hline $\mathrm{n}$ of obs & 1,183 & 1,183 & 1,183 & 1,183 & 1,183 \\
\hline
\end{tabular}


promissory notes, and real estate and less likely to receive cash. The probability of promissory notes is higher for those from Ludvika.

There are few significant results for the dummy variables measuring the relationship between donor and recipient.

During 1943, cash was a less likely type of gift. Cash was also less likely 1945-1947 while promissory notes were more likely 1945 and 1947-1949. Farm property was more likely 1946 and 1947.

Third, I have estimated conditional models for amounts in different asset categories. In this case, however, I need to use a more narrow definition of the dependent variable. The observation is only included if the particular asset is the sole asset given. Table 4 reports the estimation results.

It is clear from the table that minors receive higher amounts in stocks than others. Engineers get higher cash amounts and real estate amounts than others. Higher cash amounts but lower promissory note amounts are the outcomes for recipients from Falun, while those from Borlänge get higher stock amounts and promissory note amounts than others.

Relatives from the father's side give lower stock amounts and promissory note amounts than parents, while relatives from the mother's side give lower cash amounts and promissory note amounts. There are few significant results for the year dummy variables.

\section{Concluding remarks}

This paper has two objectives. The first is to study the revenue from the gift, inheritance, and estate taxes in Sweden during more than a century. The Swedish gift and inheritance tax was repealed in 2004. The inheritance tax in was introduced 1884 while the tax on gifts was added 1915. There was also an estate tax during the period 1948-1958.

These taxes were always controversial. One might say that they have generated more controversy than tax revenue. Gifts, inheritances, and estates were never important sources of tax revenue. Such revenue as a share of GDP reached a peak already in the 1930s.

These taxes became symbols for the ideological tension between the political left and the political right. Arguments about equity and equality of opportunity stood against property rights arguments. But these taxes also provided integrity for other tax bases, for example, the wealth tax. The existence of a gift tax made it, in other words, more difficult to avoid the wealth tax by giving wealth to others.

The second objective is to focus on a unique episode during the second half of the 1940s. Looking at tax revenue it is evident that Sweden was struck by an epidemic of sudden generosity during this period. Gift tax revenue in 1947 was twenty times higher than the annual averages before and after. This episode has never before been discussed in the research 
Table 4: Gift amounts received, logarithm, OLS.

\begin{tabular}{|c|c|c|c|c|c|}
\hline & cash & stocks & $\begin{array}{c}\text { promissory } \\
\text { notes }\end{array}$ & $\begin{array}{c}\text { real } \\
\text { estate }\end{array}$ & $\begin{array}{c}\text { farm } \\
\text { property }\end{array}$ \\
\hline \multicolumn{6}{|l|}{ recipient: } \\
\hline woman & $\begin{array}{r}-0.027 \\
(0.29)\end{array}$ & $\begin{array}{l}-0.123 \\
(1.05)\end{array}$ & $\begin{array}{l}-0.106 \\
(1.03)\end{array}$ & $\begin{array}{l}-0.172 \\
(1.07)\end{array}$ & $\begin{array}{l}0.080 \\
(0.34)\end{array}$ \\
\hline minor & -0.075 & 0.492 & 0.171 & 0.307 & -0.934 \\
\hline farm worker & $\begin{array}{c}(0.41) \\
-0.224 \\
(1.16)\end{array}$ & $(3.64)$ & $\begin{array}{c}(1.42) \\
-0.860 \\
(1.52)\end{array}$ & $\begin{array}{c}(1.15) \\
0.183 \\
(0.38)\end{array}$ & $\begin{array}{c}(1.15) \\
-0.110 \\
(0.40)\end{array}$ \\
\hline farmer & $\begin{array}{l}-0.237 \\
(1.41)\end{array}$ & $\begin{array}{l}0.368 \\
(0.76)\end{array}$ & & $\begin{array}{l}-0.323 \\
(1.49)\end{array}$ & $\begin{array}{l}0.216 \\
(0.99)\end{array}$ \\
\hline merchant & $\begin{array}{l}-0.162 \\
(0.49)\end{array}$ & $\begin{array}{l}-0.439 \\
(1.40)\end{array}$ & $\begin{array}{l}0.459 \\
(0.99)\end{array}$ & $\begin{array}{l}-1.034 \\
(1.26)\end{array}$ & \\
\hline student & $\begin{array}{l}-0.383 \\
(1.16)\end{array}$ & $\begin{array}{l}0.027 \\
(0.12)\end{array}$ & $\begin{array}{l}-0.457 \\
(1.65)\end{array}$ & $\begin{array}{l}0.156 \\
(0.30)\end{array}$ & \\
\hline engineer & $\begin{array}{r}1.052 \\
(2.25)\end{array}$ & $\begin{array}{l}0.693 \\
(1.47)\end{array}$ & $\begin{array}{c}-0.196 \\
(0.84)\end{array}$ & $\begin{array}{r}1.511 \\
(3.56)\end{array}$ & \\
\hline Falun & $\begin{array}{c}0.439 \\
(3.48)\end{array}$ & $\begin{array}{l}0.005 \\
(0.04)\end{array}$ & $\begin{array}{l}-0.273 \\
(2.12)\end{array}$ & $\begin{array}{l}0.881 \\
(1.87)\end{array}$ & \\
\hline Borlänge & $\begin{array}{l}0.239 \\
(1.26)\end{array}$ & $\begin{array}{r}0.617 \\
(2.89)\end{array}$ & $\begin{array}{r}0.584 \\
(2.76)\end{array}$ & $\begin{array}{l}0.261 \\
(0.76)\end{array}$ & $\begin{array}{l}1.163 \\
(1.63)\end{array}$ \\
\hline Orsa & $\begin{array}{l}-0.015 \\
(0.08)\end{array}$ & $\begin{array}{l}0.084 \\
(0.18)\end{array}$ & $\begin{array}{l}0.207 \\
(0.23)\end{array}$ & $\begin{array}{c}0.800 \\
(2.59)\end{array}$ & $\begin{array}{r}0.591 \\
(2.12)\end{array}$ \\
\hline Mora & $\begin{array}{l}0.747 \\
(1.83)\end{array}$ & $\begin{array}{r}-0.807 \\
(3.10)\end{array}$ & $\begin{array}{c}-0.173 \\
(0.95)\end{array}$ & $\begin{array}{l}-0.308 \\
(1.01)\end{array}$ & $\begin{array}{l}0.178 \\
(0.49)\end{array}$ \\
\hline \multicolumn{5}{|l|}{ donor: } & $\begin{array}{l}0.823 \\
(1.13)\end{array}$ \\
\hline parents & reference & reference & reference & reference & reference \\
\hline father's side & $\begin{array}{l}0.144 \\
(0.74)\end{array}$ & $\begin{array}{r}-0.733 \\
(3.52)\end{array}$ & $\begin{array}{c}-0.610 \\
(3.53)\end{array}$ & $\begin{array}{l}-0.351 \\
(0.92)\end{array}$ & $\begin{array}{l}0.498 \\
(1.28)\end{array}$ \\
\hline mother's side & $\begin{array}{c}-0.670 \\
(4.07)\end{array}$ & $\begin{array}{c}-0.243 \\
(1.08)\end{array}$ & $\begin{array}{l}-0.538 \\
(3.79)\end{array}$ & $\begin{array}{l}0.364 \\
(0.76)\end{array}$ & $\begin{array}{l}0.364 \\
(0.95)\end{array}$ \\
\hline spouse & $\begin{array}{l}0.180 \\
(0.31)\end{array}$ & $\begin{array}{l}0.297 \\
(0.65)\end{array}$ & & $\begin{array}{l}1.316 \\
(1.69)\end{array}$ & \\
\hline siblings & $\begin{array}{c}-0.326 \\
(0.82)\end{array}$ & & & $\begin{array}{l}-0.491 \\
(1.66)\end{array}$ & \\
\hline children & $\begin{array}{l}-0.734 \\
(2.05)\end{array}$ & & & $\begin{array}{l}-0.247 \\
(0.32)\end{array}$ & $\begin{array}{l}1.214 \\
(1.87)\end{array}$ \\
\hline not related & $\begin{array}{l}-0.096 \\
(0.38)\end{array}$ & $\begin{array}{l}-0.173 \\
(0.38)\end{array}$ & & $\begin{array}{l}0.312 \\
(0.59)\end{array}$ & \\
\hline \multicolumn{6}{|l|}{ year: } \\
\hline \multicolumn{6}{|l|}{1942} \\
\hline 1943 & $\begin{array}{c}0.099 \\
(0.39)\end{array}$ & $\begin{array}{c}-0.550 \\
(1.34)\end{array}$ & & $\begin{array}{l}0.079 \\
(0.15)\end{array}$ & \\
\hline 1944 & reference & reference & reference & reference & reference \\
\hline 1945 & $\begin{array}{l}0.097 \\
(0.49)\end{array}$ & $\begin{array}{l}0.060 \\
(0.16)\end{array}$ & $\begin{array}{l}0.400 \\
(0.83)\end{array}$ & $\begin{array}{l}0.340 \\
(0.70)\end{array}$ & $\begin{array}{l}-0.506 \\
(1.13)\end{array}$ \\
\hline 1946 & $\begin{array}{l}0.346 \\
(1.88)\end{array}$ & $\begin{array}{l}-0.036 \\
(0.09)\end{array}$ & $\begin{array}{l}0.231 \\
(0.46)\end{array}$ & $\begin{array}{l}-0.031 \\
(0.06)\end{array}$ & $\begin{array}{l}-0.209 \\
(0.49)\end{array}$ \\
\hline 1947 & $\begin{array}{c}0.433 \\
(2.51)\end{array}$ & $\begin{array}{l}0.135 \\
(0.36)\end{array}$ & $\begin{array}{l}0.139 \\
(0.30)\end{array}$ & $\begin{array}{l}0.481 \\
(1.03)\end{array}$ & $\begin{array}{l}-0.203 \\
(0.52)\end{array}$ \\
\hline 1948 & $\begin{array}{l}0.321 \\
(1.65)\end{array}$ & $\begin{array}{l}-0.382 \\
(0.96)\end{array}$ & $\begin{array}{l}-0.289 \\
(0.60)\end{array}$ & $\begin{array}{l}0.223 \\
(0.46)\end{array}$ & \\
\hline 1949 & $\begin{array}{l}0.284 \\
(1.46) \\
\end{array}$ & $\begin{array}{l}-0.101 \\
(0.23) \\
\end{array}$ & $\begin{array}{l}-0.537 \\
(1.09) \\
\end{array}$ & $\begin{array}{l}-0.380 \\
(0.78) \\
\end{array}$ & $\begin{array}{r}-1.825 \\
(4.04)\end{array}$ \\
\hline$R^{2}$ & 0.180 & 0.287 & 0.238 & 0.440 & 0.625 \\
\hline adjusted $R^{2}$ & 0.117 & 0.201 & 0.183 & 0.310 & 0.503 \\
\hline$F$, model, sign. & 0.000 & 0.000 & 0.000 & 0.000 & 0.000 \\
\hline root MSE & 0.776 & 0.749 & 0.782 & 0.742 & 0.600 \\
\hline $\mathrm{n}$ of observations & 340 & 195 & 268 & 128 & 62 \\
\hline
\end{tabular}


literature. It gives an extremely clear illustration of behavioral response to taxes in general, and the impact of expectations of future tax increases in particular.

A main result is that gift tax revenue during the 1940s started to increase long before a new estate tax and increased wealth taxation was decided and implemented. It started even before the legislative process started.

I have constructed a rich micro data set of all gifts reported during the period 1942-1949 in Dalarna, a county in the geographical middle of the country. Using this data set I can show that both the number and the average values of gifts increased. Promissory notes were, in value, by far the most common way to give.

An important issue is whether the households were right in advancing their transfers to younger generations. Was it rational to take the actions that the households did? In the short run it was quite obvious that this was the case as the estate tax on gifts did not apply to gifts made before 1948 . But with a more long run perspective this becomes more of an open question. It depends on how much earlier the transfer was made compared to when it had been made as a bequest or as a later gift. This is an important topic for future research as it will shed more light on the question of the effects of taxes on behavior.

The gift explosion during the second half of the 1940s is also a very interesting episode in the economic history of Sweden. It is obvious that there was a clear correlation between gifts and politics. But what was the causality between the events in the political and the private sphere? On the one hand, was the giving a reaction on policy based on private economic considerations? Or were there political motives for the giving? I regard it as less likely that the giving had direct political motives, this was in any case not reflected in the political discussion. Instead it is more likely that private concerns were more important.

On the other hand, did the opinions among those giving form the political basis for the opposition to the estate tax? This seems more likely to me. But the question of causality in this case is an important topic for future research on Sweden's economic history. 


\section{Appendix A: Data sources and descriptive statistics}

\section{Macro data}

I have collected tax revenue from the following sources:

\begin{tabular}{|c|c|c|c|}
\hline type & period & title & published by \\
\hline calendar year & $1884-1914$ & $\begin{array}{l}\text { Uppgift för år (1886-1914) enligt föreskrift } \\
\text { i nådiga brefvet den } 12 \text { September } 1884 \text { " }\end{array}$ & \\
\hline calendar year & $1915-1947$ & $\begin{array}{l}\text { Statistik över användningen av dubbla } \\
\text { beläggningsstämplar år (1906-1947) }\end{array}$ & Statistics Sweden \\
\hline biannual & $1938-1947$ & $\begin{array}{l}\text { Statistik över användningen av dubbla } \\
\text { beläggningsstämplar år (1938-1947) }\end{array}$ & Statistics Sweden \\
\hline budget year & $1947 / 48-1959 / 60$ & Budgetredovisning & the National Accounting Bureau \\
\hline budget year & $1960 / 61-1979 / 80$ & Budgetredovisning & the National Audit Bureau \\
\hline budget year & $1980 / 81-1994 / 95$ & Statsbudgetens utfall & the National Audit Bureau \\
\hline calendar year & $1995-1997$ & Statsbudgetens utfall & the National Audit Bureau \\
\hline calendar year & 1998-2006 & Statsbudgetens utfall & $\begin{array}{l}\text { the National Financial } \\
\text { Management Authority }\end{array}$ \\
\hline
\end{tabular}

It will be possible to download the time series for revenue from inheritance, estate, and gift taxes from my web page $<$ http://www.anst.uu.se/henryos/ $>$ in the future.

The source of the time series for GDP by activity, basic prices, 18842000, is Rodney Edvinsson's Current values of GDP and other aggregate variables in Sweden 1800-2000, <http://www.historia.se/tableB.xls $>$. The data for 2001-2006 have been obtained by direct communication with him.

\section{Micro data}

The source of the micro data from Dalarna is: Länsstyrelsen i Kopparbergs län, Landskontoret, Diarier för gåvo- och kvarlåtenskapsskatt. This register has the reference code SE/ULA/11031/B I h: 1 in the National Archives register. It can be found in the Regional Archives in Uppsala.

I have punched the following variables from the register:

- diary number

- date

- family name

- first names

- maiden name

- gender (coded from the first names) 
- title (minor and occupation can be coded from the title)

- street address

- postal address

- first gift amount

- first gift type

- second gift amount

- second gift type

- relationship to donor

- tax amount

- comments

Each gift is one observation. Some recipients get more than one gift, and some donors give more than one gift. Table 5 reports the descriptive statistics for the main variables used in the paper. The standard deviations are not reported for dummy variables as the spread follows from the mean. 
Table 5: Descriptive statistics.

\begin{tabular}{|c|c|c|c|c|c|}
\hline variable & $\mathrm{n}$ of obs & mean & std. dev. & $\min$ & $\max$ \\
\hline gift, SEK & 1,519 & 16,852 & 19,595 & 0 & 150,000 \\
\hline gift tax, SEK & 1,373 & 747 & 1,528 & 0 & 13,124 \\
\hline tax share & 1,331 & .0292 & .0252 & 0 & .2156 \\
\hline woman & 1,542 & .462 & & & \\
\hline minor & 1,230 & .255 & & & \\
\hline farm worker & 1,230 & .036 & & & \\
\hline farmer & 1,230 & .079 & & & \\
\hline merchant & 1,230 & .019 & & & \\
\hline student & 1,230 & .036 & & & \\
\hline engineer & 1,230 & .023 & & & \\
\hline Falun & 1,546 & .164 & & & \\
\hline Borlänge & 1,546 & .050 & & & \\
\hline Orsa & 1,546 & .055 & & & \\
\hline Mora & 1,546 & .050 & & & \\
\hline Ludvika & 1,546 & .047 & & & \\
\hline parents & 1,494 & .770 & & & \\
\hline father's side & 1,494 & .086 & & & \\
\hline mother's side & 1,494 & .096 & & & \\
\hline spouse & 1,494 & .007 & & & \\
\hline siblings & 1,494 & .017 & & & \\
\hline children & 1,494 & .006 & & & \\
\hline not related & 1,494 & .016 & & & \\
\hline 1942 & 1,563 & .055 & & & \\
\hline 1943 & 1,563 & .061 & & & \\
\hline 1944 & 1,563 & .045 & & & \\
\hline 1945 & 1,563 & .118 & & & \\
\hline 1946 & 1,563 & .131 & & & \\
\hline 1947 & 1,563 & .363 & & & \\
\hline 1948 & 1,563 & .148 & & & \\
\hline 1949 & 1,563 & .079 & & & \\
\hline
\end{tabular}




\section{Appendix B: The gift tax rates in the mid 1940s}

The tax schedules that applied during the gift explosion 1947 were introduced 1942 but there were no major changes compared to the rates introduced in the beginning of the 1930s. There were four different schedules depending on consanguinity. The basic exemption for gifts to children was SEK 3,000. The top marginal tax rate was 20 percent, it applied to gift amounts higher than SEK 400,000. Taxable gift amounts were integrated with the inheritance tax.

The average gift from parents to children in the Dalarna sample was SEK 19,100. The marginal tax rate for this amount was 4 percent, while the average tax rate was 2.7 percent. Total taxes on parents' gifts to children as a share of parents' total gifts to children was 4.3 percent.

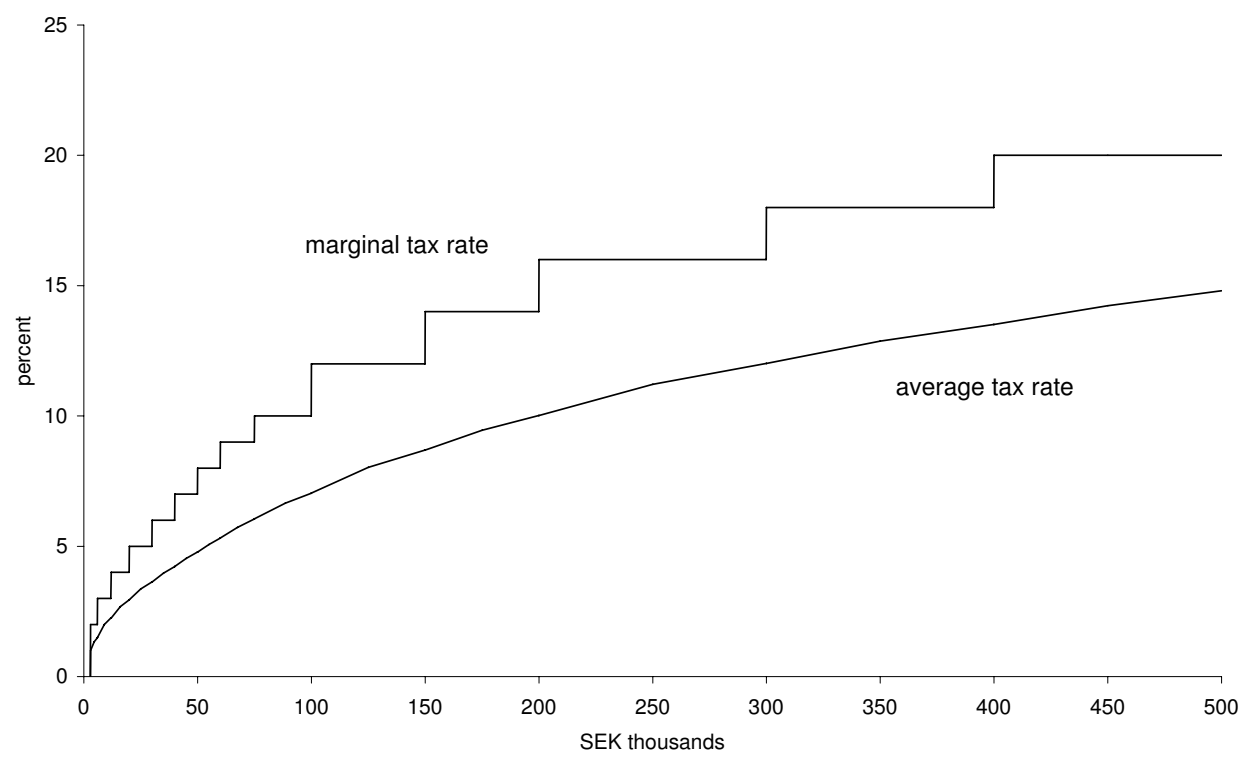

Figure 5: Marginal and average tax rates on gifts to children, mid 1940s, percent. 


\section{Appendix C: Chronology}

1660-1664 A stamp ordinance stipulated that wills, estate reports, and estate divisions should be written on stamped paper.

1686 A stamp ordinance reintroduced the stamp duty on wills, estate reports, and estate divisions.

1698 The 1698 Royal Ordinance on poor relief stipulated a 1/8 percent duty on gross assets of estates and a $1 / 2$ percent stamp duty on wills. The tax revenue was for local governments.

1734 Estate reports became mandatory.

1752 The 1752 Royal Ordinance on estate duty introduced a $1 / 4$ percent duty on estates.

1810 The 1810 appropriation ordinance introduced the first real gift tax.

the mid 1800s The estate report became the only object of stamp duty. The stamp depended on the estate value so this was an estate tax. In addition, there were stipulations about taxation of inheritances in the appropriation ordinance.

1884 The 1884 stamp ordinance meant that the different taxes were merged into a single tax with the estate report as the base. The rate was 0.5 percent if there were legal heirs, 0.6 percent otherwise. The appropriation on gifts was removed, a stamp duty on gifts involving title deeds was introduced.

1894 The 1894 stamp ordinance introduced the first modern inheritance tax. The maximum rate was 6 percent. The stamp duty on gifts was widened to include deeds of gifts.

1914 The 1914 inheritance and gift tax ordinance introduced the first modern gift tax.

1933 The government proposed an estate tax, but this was turned down by Parliament. The taxes on inheritances and gifts were increased instead.

1934 The government once again proposed an estate tax and failed in Parliament. This time an independent wealth tax was introduced instead.

1941 The 1941 inheritance and gift tax ordinance introduced changes in these taxes. 
1947 The 1947 estate tax ordinance introduced an estate tax.

1957 The report of the official committee on inheritance taxation suggested that the estate tax should be repealed. Parliament followed the suggestion, the estate tax was removed from 1959. The taxes on inheritances and gifts were increased instead.

2003 The inheritance tax was removed for bequests to spouses.

2004 Parliament decided December 17 to repeal the inheritance and gift tax. 


\section{References}

Eberstein, G. (1948). Kvarlåtenskapsskatten i kritisk belysning. Norstedt, Stockholm.

Eberstein, G. (1956). Den svenska arvslotts- och gåvobeskattningen. Stockholm, 2 edition.

Elvander, N. (1972). Svensk skattepolitik 1945-1970. Rabén \& Sjögren, Stockholm.

Englund, G. and Silfverberg, C. (1997). Beskattning av arv och gåva. Norstedts, Stockholm, 11 edition.

Erlander, T. (1973). 1940-1949. Tiden, Stockholm.

Erlander, T. (2001). Dagböcker 1945-1949. Gidlunds förlag, Hedemora.

Joulfaian, D. (2004). Gift taxes and lifetime transfers: time series evidence. Journal of Public Economics, 88(9-10):1917-1929.

Lindgren, H. (2002). The modernization of Swedish credit markets, 1840 1905: Evidence from probate records. Journal of Economic History, $62(3): 810-832$.

Nationalekonomiska Föreningen (1948). De nya skatteförslagen, sammanträde den 14 januari 1947. In Förhandlingar 194\%, pages 1-31, Stockholm. Hæggströms.

Ohlin, B. (1975). Memoarer 1940-1951. Socialistisk skördetid som kom bort. Bonniers, Stockholm.

SOU (1946). Betänkande med förslag till omläggning av den direkta statsbeskattningen samt angående kvarlåtenskapsskatt. Statsskatteberedningen, SOU 1946:79. Stockholm.

SOU (1957). Arvsbeskattning. Betänkande av Arvsskattesakkunniga, SOU 1957:48. Stockholm.

Wigforss, E. (1954). Minnen III 1932-1949. Tiden, Stockholm. 
WORKING PAPERS*

Editor: Nils Gottfries

2006:24 Martin Ågren, Prospect Theory and Higher Moments. 31pp.

2006:25 Matz Dahlberg, Eva Mörk, Jørn Rattsø and Hanna Ågren, Using a discontinuous grant rule to idenitfy the effect of grants on local taxes and spending. 26pp.

2006:26 Jukka Pirttiläa and Håkan Selin, How Successful is the Dual Income Tax? Evidence from the Finnish Tax Reform of 1993. 40pp.

2006:27 Henrik Jordahl and Che-Yuan Liang, Merged Municipalities, Higher Debt: On Free-riding and the Common Pool Problem in Politics. 34pp.

2006:28 Per Engström, Ann-Sofie Kolm and Che-Yuan Liang, Maternal Addiction to Parental Leave. 18pp.

2006:29 Jonas Björnerstedt and Andreas Westermark, Delay in Bargaining with Externalities. 27pp.

2006:30 Pär Österholm, Incorporating Judgement in Fan Charts. 36pp.

2006:31 Mikael Carlsson and Andreas Westermark, Monetary Policy and Staggered Wage Bargaining when Prices are Sticky. 26pp.

2007:1 Mikael Elinder, Local Economies and General Elections. 26pp.

2007:2 Ouarda Merrouche, The Long Term Impact of French Settlement on Education in Algeria. 19pp.

2007:3 Ouarda Merrouche, The Long Term Effect of Education Spending Decentralization on Human Capital in Spain. 15pp.

2007:4 Erik Post, Macroeconomic imbalances and exchange rate regime shifts. 38pp.

2007:5 Christian Andersson, Teacher density and student achievement in Swedish compulsory schools. 31pp.

2007:6 Thomas Aronsson, Sören Blomquist and Luca Micheletto, Where Should the Elderly Live and Who Should Pay for their Care? A Study in Demographics and Geographical Economics. 22pp.

2007:7 Sören Blomquist and Vidar Christiansen, Public Provision of Private Goods and Nondistortionary Marginal Tax Rates. 17pp.

2007:8 Marcus Eliason and Henry Ohlsson, Living to Save Taxes. 13pp.

\footnotetext{
* A list of papers in this series from earlier years will be sent on request by the department.
} 
2007:9 Åsa Ahlin and Eva Mörk, Effects of decentralization on school resources: Sweden 1989-2002. 31pp.

2007:10 Henry Ohlsson, The equal division puzzle - empirical evidence on intergenerational transfers in Sweden. 20pp.

2007:11 Daniel Hallberg and Mårten Lagergren, Moving in and out of public geriatric care in Sweden. 26pp.

2007:12 Per Engström, Wage Formation and Redistribution. 22pp.

2007:13 Henry Ohlsson, Tax avoidance - a natural experiment. 21pp.

2007:14 David Kjellberg and Erik Post, A Critical Look at Measures of Macroeconomic Uncertainty. 27pp.

2007:15 Mikael Carlsson and Andreas Westermark, Optimal Monetary Policy under Downward Nominal Wage Rigidity. 52pp.

2007:16 Robin Douhan and Anders Nordberg, Is the elephant stepping on its trunk? The problem of India's unbalanced growth. 33pp.

2007:17 Annika Alexius and Bertil Holmlund, Monetary Policy and Swedish Unemployment Fluctuations. 27pp.

2007:18 Meredith Beechey and Pär Österholm, The Rise and Fall of U.S. Inflation Persistence. 23pp.

2007:19 Henry Ohlsson and Donald Storrie, Long term effects of public policy for displaced workers in Sweden - shipyard workers in the West and miners in the North. 26pp.

2007:20 Niklas Bengtsson, How responsive is body weight to transitory income changes? Evidence from rural Tanzania. 38pp.

2007:21 Karin Edmark, Strategic Competition in Swedish Local Spending on Childcare, Schooling and Care for the Elderly. 38pp.

2007:22 Fredrik Johansson, How to Adjust for Nonignorable Nonresponse: Calibration, Heckit or FIML? 25pp.

2007:23 Henry Ohlsson, The legacy of the Swedish gift and inheritance tax, 18842004. 25pp.

See also working papers published by the Office of Labour Market Policy Evaluation http://www.ifau.se/ 